\title{
The Genesis and Evolution of the Caspian Sea Lagoons as Avifauna Refuges at the Transboundary Scale
}

\author{
Evgeny Viktorovich Vilkov \\ Caspian Institute of Biological Resources, Daghestan Scientific Centre, Russian Academy of Sciences, \\ Makhachkala, Russia \\ Email: evberkut@mail.ru
}

Received 9 December 2015; accepted 26 January 2016; published 29 January 2016

Copyright (C) 2016 by author and Scientific Research Publishing Inc.

This work is licensed under the Creative Commons Attribution International License (CC BY). http://creativecommons.org/licenses/by/4.0/

(c) (i) Open Access

\section{Abstract}

The article summarizes 34 years $(1980-2014)$ of the original observations of the genesis and evolution stages of the Caspian lagoons. A model of the formation and evolution of the coastal lagoons has been worked out. It can be applied to the modelling of the global geoecological scenario along all the world's coasts characterized by a steady transgression of their marine areas. The lagoons had been formed in a "bottleneck", a narrow migration corridor, traversed by the largest migration route of trans-Palearctic species in Russia. This route is part of the West Siberian-East African migration range. Year round bird censuses $(n=746)$ were taken by the author in 1995-2014 along two key routes in the regions of Turalinskaya and Sulakskaya lagoons of Daghestan (the western coast of the Middle Caspian Sea). The meridional orientation of lagoons, location of the migration trajectory and a wide range of habitats in the study area contribute to the preservation of 294 Eurasian bird species. After formation of the lagoons, the breeding avifauna of the Caspian Sea Region of Central Daghestan has added 32 taxa. Among the species recorded at the lagoons, 50 are included in the IUCN Red List, Red Data Books of Russia and Daghestan. The reconstruction analysis of the migration trajectory compiled according to the data of the Russian Bird Ringing Centre allowed us to determine the population distribution geography for the birds regularly migrating along the western coast of the Caspian Sea and refine borders of the West Siberian-East African migration range. Thus, according to the information received, the current migratory range should be greatly extended to cover the area from the British Isles in the West Palearctic to Lake Baikal in the east, including the extreme west and south of Africa.

\section{Keywords}

Western Coast of the Caspian Sea, Daghestan, Lagoon Evolution, Conservation of Eurasian Birds 


\section{Introduction}

In the context of global warming, accompanied by a tendentious rise of the World Ocean [1] and increase in the level of some seas including the Caspian Sea, the conservation issues of coastal wetland ecosystems and waterbirds have become particularly relevant, especially since the waterbird abundance has markedly reduced in recent years [2]-[5]. In fact, seacoasts and their wetlands are not only major landscape lines directing bird flows in the migration season but provide territories for stopovers as well as nesting and summering grounds. The emergence or disappearance of wetland ecosystems along the busy flyways may provoke changes in bird concentration areas. Alongside with resource and nature conservation consequences, it may also entail important political and economical effects, since the migratory birds are regarded as transboundary and, thus, international assets. The quality and universality of the applied coastal transformation pattern are main factors determining the successful modelling of the global geoecological scenario along the world's coasts characterized by a steady transgression of their marine areas. Against this background, it is especially important to predict redistribution in bird communities induced by the emergence or disappearance of large marine lagoons. In this regard, the protection of migratory birds and their habitats has become a global objective of the Convention on the Conservation of Migratory Species of Wild Animals (CMS) [6].

The western coast of the Middle Caspian Sea was chosen as a test area to detect geoecological and ornithological changes in the transgressing Caspian Sea Region. It contains a complex of marine lagoons, which is traversed by one of the largest migration routes of trans-Palearctic species in Russia [7]. This route is part of the West Siberian-East African migration range [8] (Figure 1) delimited previously on the basis of the West Siberian-Caspian-Nile flyway [8].

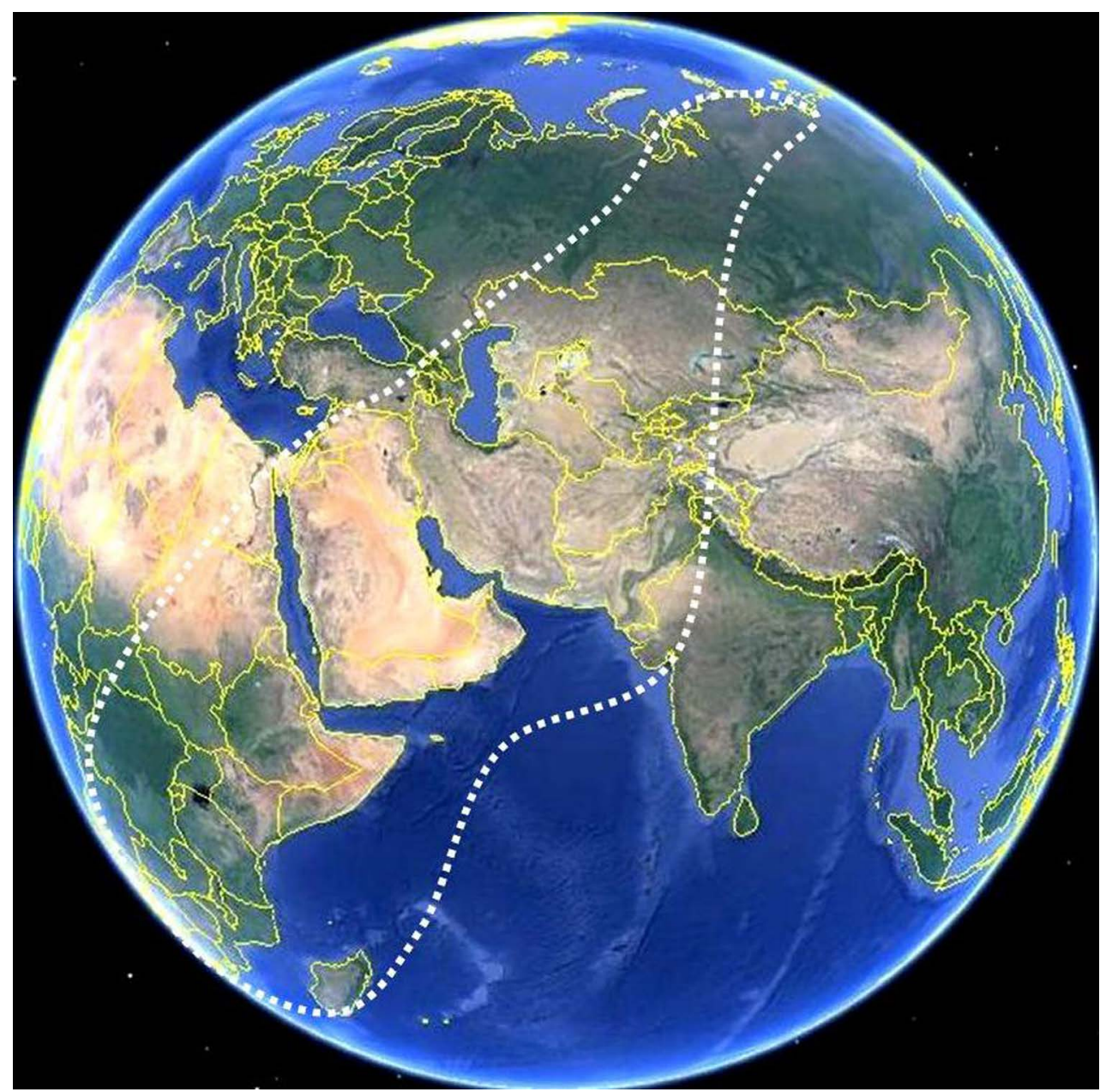

Figure 1. West Siberian-East African migration range [17]. 
The migration trajectory passes through a "bottleneck", a narrow 4 - 5 km migration corridor lying on one of the key census routes (in the Turalinskaya Lagoon) (Figure 2). This considerably facilitates the above task, since the species included in analysis naturally concentrate in these areas during different periods of their biological cycles. The bottleneck is formed by the frontal ridges of the Eastern Caucasus (up to $1000 \mathrm{~m}$ a.s.l.) protruding at an angle of $90^{\circ}$ into the Caspian Depression in the west and by the Caspian Sea coastline in the east. The nesting ranges of birds that belong to the considered group of trans-Palearctic migrants concentrate in different areas of the Arctic, Subarctic, West Siberian Plain, and Kazakhstan. Their wintering grounds lie in the Southern Caspian Region, India (mostly those of larid birds), countries of the Middle East, the Nile Delta, and North-Eastern Africa ([8] [9], data of the Russian Bird Ringing Centre, Severtsov Institute of Ecology and Evolution, Russian Academy of Sciences).

Specific features of spatial relationships between the majority of long-distance migrant species and certain commonality of relevant periodic phenomena in the Caspian region allow this bird assemblage to be regarded as a single entity, which makes it necessary to develop a unified strategy for the conservation and exploitation of migratory bird resources for the common benefit of all the Caspian states. Therefore, the West Caspian flyway should be viewed as a key link in the differentiated space of the ranges of birds that belong to the trans-Palearctic group of migrants annually flying along the western coast of the Caspian Sea from their nesting areas in the north to traditional wintering grounds in the south.

Long-term rises and falls in the Caspian Sea level determined by the dynamics of global hydroclimatic processes lead to synchronous redistribution of bird habitats [7] [10]. One of such changes in climate phases, from dry and warm to wet and cool [10], resulted in a dramatic transgression of the Caspian Sea (1978-1996) [11]; as a consequence, a complex of brackish lagoons free of above-water vegetation formed along the central part of the western coast of the Middle Caspian Sea in the last quarter of the $20^{\text {th }}$ century [5] [12]-[14].

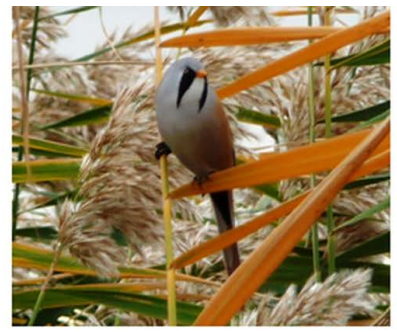

a. Panurus biarmicus

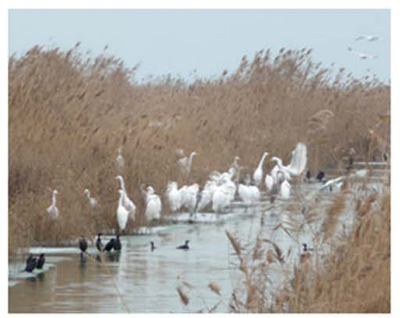

b. Egretta alba, Phalacrocorax pygmaeus

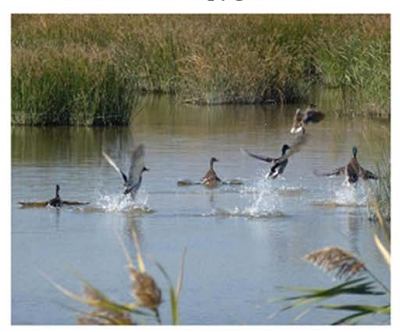

c. Anas platyrhynchos

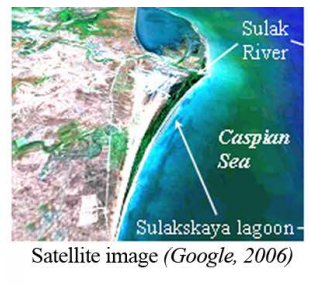

$$
\text { Trajec }
$$

Trajectory of trans Palearctic bird migration

西

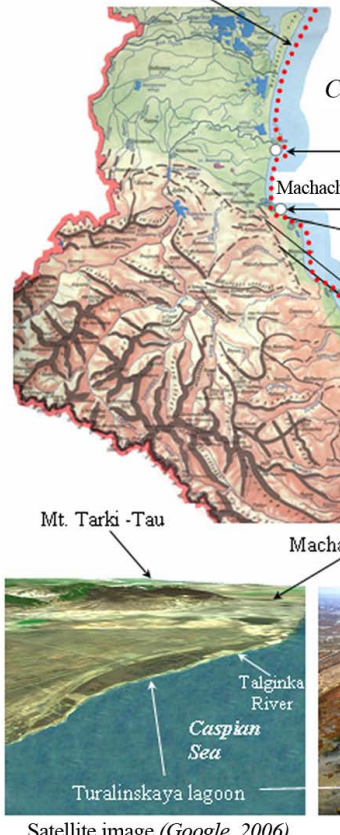

Satellite image (Google, 2006)

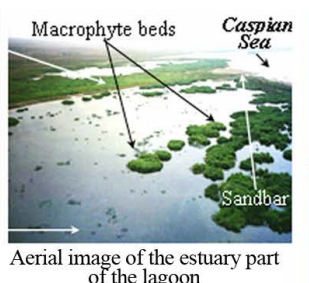

$\mathrm{W}-\underset{\mathrm{S}}{\mathrm{N}}$

Caspian Sea

Sulakskaya lagoon

Turalinskaya lagoon

$\rightarrow$ Bottleneck

corridor

Height of ridges:

- - more low $1000 \mathrm{~m}$

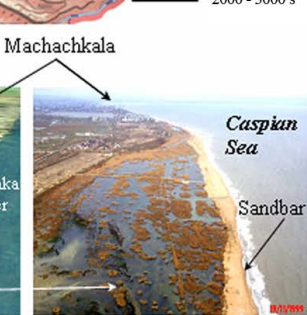

Aerial image (1999)

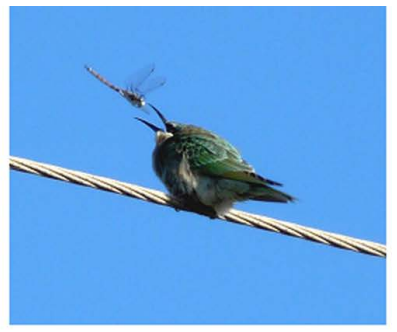

d. Merops superciliosus

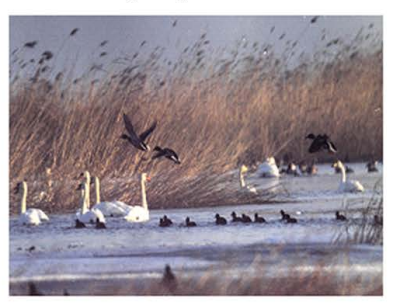

e. Cygnus olor, Fulica atra,

Anas platyrhynchos

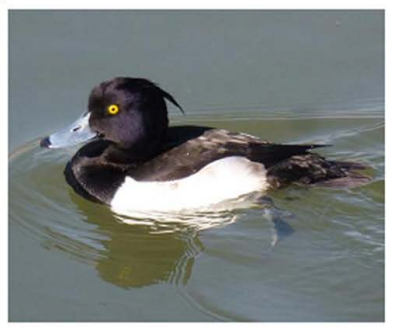

f. Aythya fuligula

Figure 2. Schematic map showing locations of the lagoons, the migration corridor and the trajectory of transPalearctic bird migration. e - f: birds of the Daghestan lagoons (author's photo). 
For the first 10 - 15 years of intensive succession changes the lagoons have acquired features of eutrophic wetland ecosystems with abundance of food resources and diverse habitats attracting a wide group of birds with various ecological adaptations.

The relevance of this study is in the fact that long-term trends in the abundance of bird species have been revealed during a period of active hydroclimatic shifts. Such a period is optimal for inventorying wetland areas, since it provides the possibility to evaluate the significance of all wetland ecosystems for the preservation of birds comprising the aquatic-wetland assemblage, whereas during warm and dry climatic phases many such ecosystems lose this significance.

\section{Material and Methods}

The 34 years (1980-2014) of the original observations added by published data [11] [15] were used to reconstruct mechanisms for the genesis and evolution of the Caspian lagoons.

The faunistic material was summarized according to year round bird censuses taken by the author over the period from 1995 to 2014 in the regions of Sulakskaya Lagoon $\left(42^{\circ} 13^{\prime} \mathrm{N}, 47^{\circ} 30^{\prime} \mathrm{E}\right.$; area $\left.1080 \mathrm{ha}\right)$ and Turalinskaya Lagoon ( $42^{\circ} 56^{\prime} \mathrm{N}, 47^{\circ} 35^{\prime} \mathrm{E}$; area $250 \mathrm{ha}$ ), Daghestan. The censuses were taken by the generally accepted method [16] [17] in the daytime (mostly from 7:30 a.m. to 13:30 p.m.) along pedestrian stationary routes 5 to $14 \mathrm{~km}$ long. The frequency of the censuses was three to five times per month, at 7- to 10-day intervals. The zone of regular monitoring covered up to $40 \%-80 \%$ of the total area of the lagoons and extended over the seacoast and the adjacent land area from the continental parts of the bays to the nearest mountains of the Eastern Caucasus. A total of 746 censuses were taken during the 19-year period, with the total route length and census time amounting to $4495 \mathrm{~km}$ and $3062 \mathrm{~h}$. More than 5000 pictures of birds were taken in lagoons and adjacent areas.

\section{Results and Discussion}

Regardless of significant changes in the Caspian Sea level for the whole period of observations since 1837 [10], there was not any dramatic transformations in geoecological structure of the Caspian coasts. Starting from 1979 the Caspian level has been rapidly rising [18], and between the late 1970s and mid 1990s the water surface of the sea increased from 370 to $452 \mathrm{~km}^{2}$ [19] (Figure 3).

It resulted in structural geoecological changes in some areas of the Daghestanian coast in the Middle Caspian Region and consequently led to the formation of new aquatic ecosystems - brackish lagoons [13], among which Sulakskaya and Turalinskaya became the most valuable for birds (Figure 2).

A formation mechanism of coastal barriers (bars) and, subsequently, lagoons is based on the ratio between the gradient of underwater slope (USL) and the gradient of adjacent land area [15]. The range of underwater slopes gradients facilitating the formation of coastal barriers lies within 0.001 - 0.01 (Figure 4). The process of shoreline

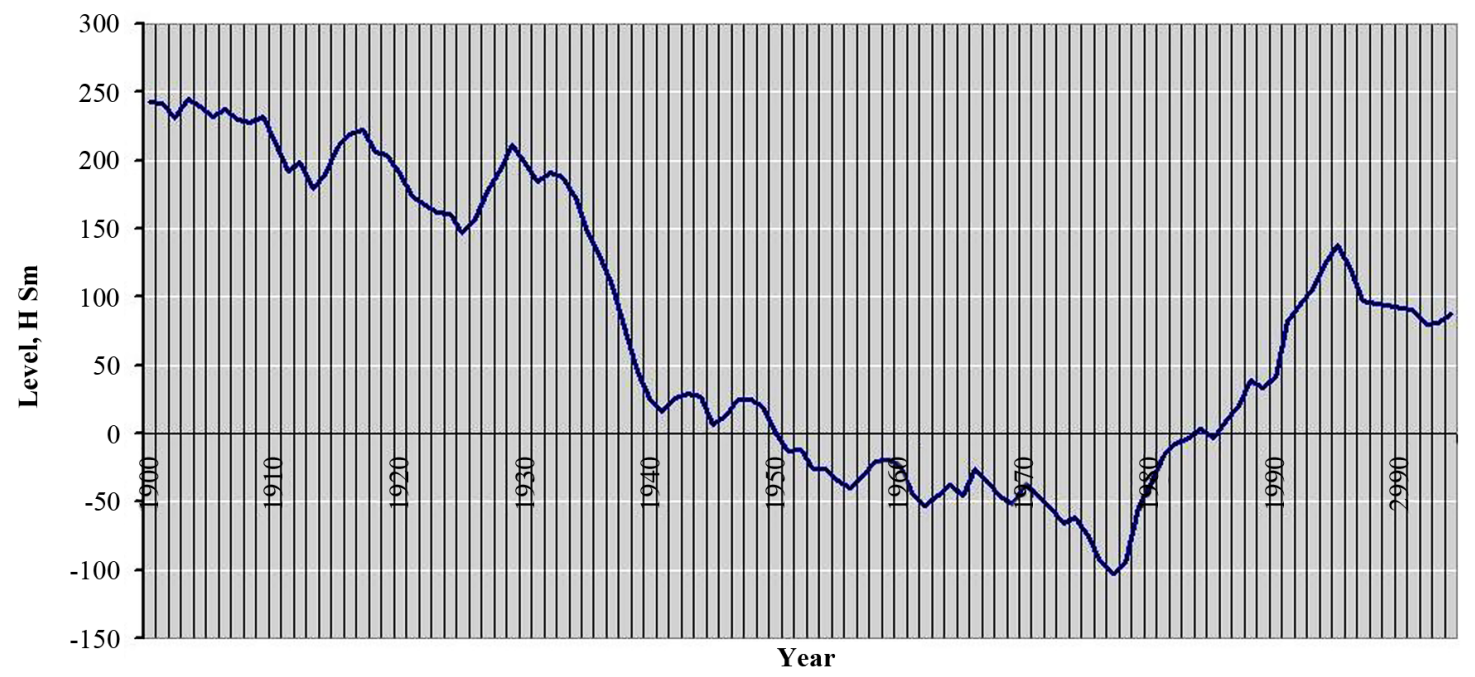

Figure 3. Average annual changes in the Caspian Sea level according to the data of the Makhachkala gauging station in cm above " 0 " of the station, equalling minus 28 a.s.l. 


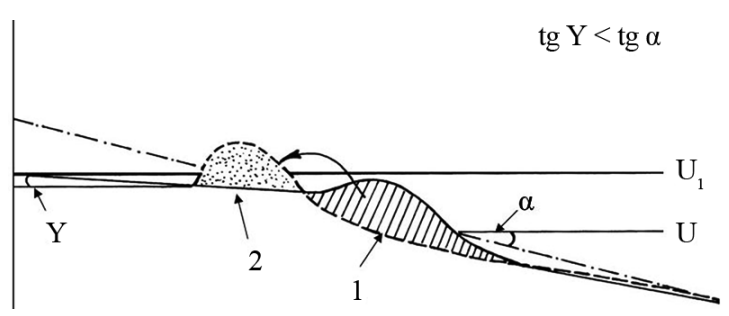

Figure 4. Schematic map showing the development of the coastal barrier [11]. Notes: 1 -erosion; 2-accumulation; $\mathrm{U}$-original profile; $\mathrm{U}_{1}$-new level; $\operatorname{tg} \alpha$-gradient of the underwater continental slope; tgY-gradient of the adjacent land area.

retreat is also determined by the USL gradient, and coastal barriers are beginning to develop only when the USL gradient exceeds that of the adjacent land area. The higher is the USL gradient the higher and steeper is the coastal barrier that is formed. At this, the type of the coast itself does not change.

The scheme of the coast transformation in the context of the transgressing Caspian Sea corresponds to the rule of Zenkovih-Bruun and can be conveniently approximated by the following equation: $\mathrm{X}=\mathrm{Y} / \operatorname{tg} \alpha$, where $\mathrm{X}$ is the retreat of shoreline, Y - the sea level rise, tg $\alpha$ - USL gradient by isobath, which demarcates noticeable deformations of the bottom arising in the course of on-going transformation of the underwater slope. With further rise of the sea level the water depth above the underwater slope increases and the incoming wave energy changes the USL profile. In cases when the adjacent land is plain and inclined to the sea at the angle smaller than the balance profile of the underwater slope $(\operatorname{tg} Y<\operatorname{tg} \alpha)$, there are real prerequisites for the formation of the coastal barrier. When the balance between gradients is disturbed, most of erosion products move up the profile and accumulate behind the ridge of the coastal barrier thus contributing to its growth. In the context of dramatic transgression of the Caspian Sea the shoreward movement of the barrier is lagging, and the total distance it would have moved increases with every year. As a result, it comes a moment when the surface of the regressive terrace behind the coastal barrier sinks below sea level, and joint actions of the sea waters soaking through and overflowing the sand ridge along with the increasing pressure of ground waters and those coming from the adjacent land finally make a lagoon behind the coastal barrier.

The lagoon formation process includes several subsequent phases [13] (Figure 5): 1) Flooding of coasts and formation of numerous proto-lagoons (1980-1986); 2) Merging of proto-lagoons and formation of more stable medi-lagoons (1986-1994); 3) Merging of medi-lagoons with simultaneous development of the estuary and formation of a full-profile lagoon (1994-1996) or a pseudo-estuary, to be more specific in our case.

As a result of long-term dynamic processes, the lagoons from open bodies of water turned into desalinated wetlands with well-developed wetland vegetation. It has essentially improved the ecological situation in large part of the Central Daghestan Caspian Region. The optimized ecological conditions along the flyways have brought changes in the qualitative and quantitative composition of birds in their type of migration behaviour and changed the terms and status of residence for some taxa [5] [14].

Uncovering specific features of migrations along the western coast of the Caspian Sea we should explain that the Caspian coast lies across temperate continental, moderately warm and subtropical climate zones and is a good benchmark for ecologically diverse groups of birds on their way to the wintering grounds. According to its ecological characteristics (availability of large sea bays and lagoons, large river deltas and lake systems) the western coast of the Caspian Sea represents a highly favourable trajectory for migratory birds. That is why the migration rate at the western coast of the Caspian Sea is 14.9 times greater than along its eastern one [7]. At the same time, the southern location of the Caspian Sea defines the presence of large wintering assemblages of hydrophilous birds. It supports their active migration and provides suitable stopovers making a great contribution in the conservation of regular Palearctic migrants. Against this background, the Daghestan lagoons play an important role of key refuges facilitating the preservation of migratory and wintering birds in critical periods of their life cycle.

Over the period of 19-year monitoring in Sulakskaya and Turalinskaya lagoons a total of 294 bird species were recorded [5]. They are classified all follows: 200—migratory; 23—resident; 32—nesting migrants or birds of passage; 10 -formerly nesting (at early stages of lagoon successions); 4 —upposedly nesting; 9 —nesting not every year; 58-wintering; 20-wintering transiently; 21-summering; 69-accidental; 21—those flying in from adjacent areas (visitors) and 6 species were registered by the author for the first time in Daghestan (Branta 


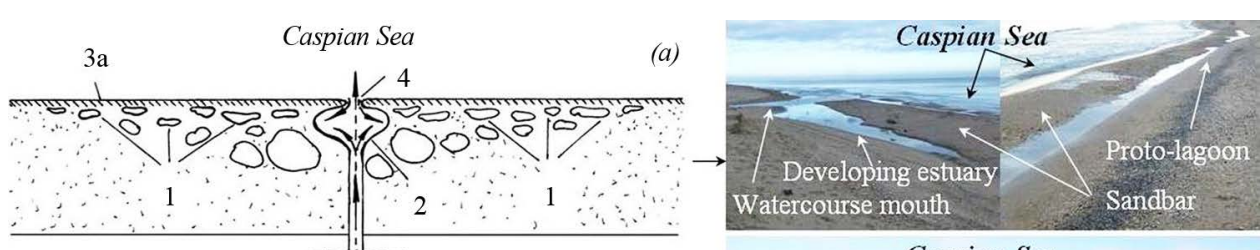

$\rightarrow$ Caspian Sea

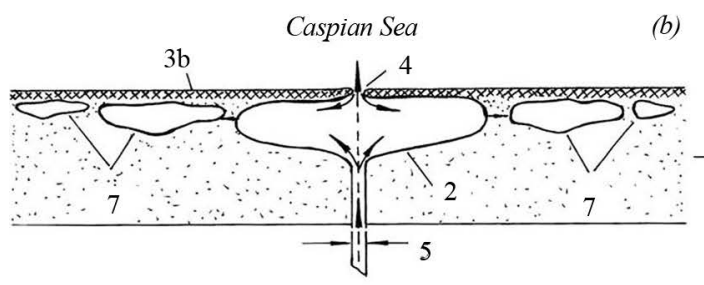

(b)
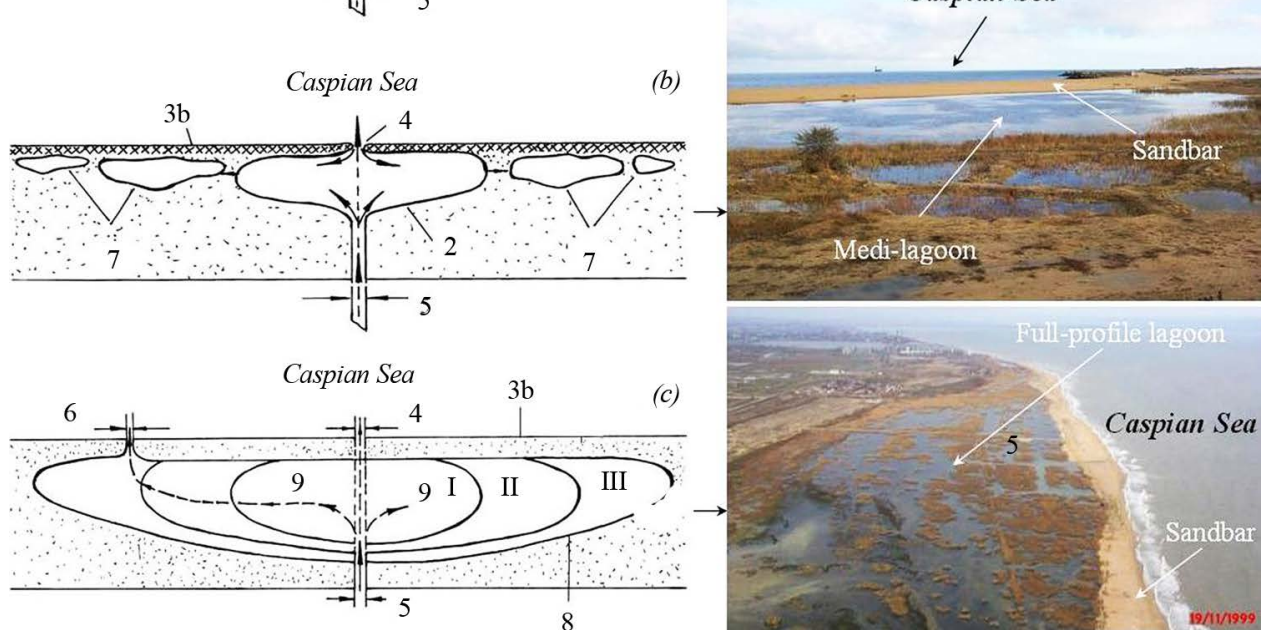

Figure 5. Stages of the lagoon formation (photo-reconstruction of the lagoon formation stages corresponds to graphic images of the lagoon evolution). Notes: (a) proto-lagoon, (b) medi-lagoon, (c) full-profile lagoon (pseudo-estuary). 1. Proto-lagoons; 2. Estuary; 3a-Coastal barrier; 3bCoastal bar; 4. Primary mouth of the watercourse; 5 . Channel of the watercourse; 6 . Secondary mouth of the watercourse; 7. Medi-lagoons; 8. Full-profile lagoon (pseudo-estuary); 9. Direction of water flow in the lagoon; I-mature part of the lagoon, the most developed in biotopical respect; II-middle-aged part of the lagoon; III-juvenile part of the lagoon.

Canadensis, Clangula hyemalis, Calidris ruficollis, Calidris subminuta, Numenius tenuirostris, Uragus sibiricus).

Faunal diversity of lagoons is determined by a number of their natural features:

First - desalinated wetlands have been formed in arid regions of the Western Caspian Region with the continuing deficit of fresh water that made birds localise in desalinated lagoons; second-under the influence of biocoenosis environment-forming activity the lagoons for the first 10 - 15 years of their existence have acquired features of well-developed wetland ecosystems providing abundance of food, good shelter and a set of diverse habitats; third - the lagoons have physically isolated extensive areas of the seacoast $(\approx 35 \mathrm{~km})$ and excluded the possibility of their intensive anthropogenic exploitation as recreation sites. It considerably strengthened the "oasis" effect of the lagoons; fourth - the lagoons have a favourable location lying on the busy flyways and some birds changed from facultative to obligate participation in the lagoon bird communities; fifth - the southern location of the lagoons at the western coast of the Middle Caspian Sea predetermined their relation to the zones of "mild" or "warm" wintering that welcomed regular occurrence of large assemblages of wintering birds in the winter season; sixth - the lagoons are located in highly urbanized regions of Daghestan where intensive cultivation of natural areas is accompanied by dramatic landscape changes. As a result, the Caspian Depression is currently going through active redistribution of avifauna, and birds are forced out to various natural refuges (lagoons, in particular); seventh - the formation of new ecological shelters for waterbirds with actively growing food and nesting capacities facilitated the development of a breeding population of hydrophilous birds in the study area, which had not been typical earlier for large part of arid ecosystems of the Central Daghestan Caspian Region.

Estimating the lagoons with regard to their potential as bird habitats we should note that after their formation the nesting avifauna of the Central Daghestan Caspian Region has added 32 taxa [12].

The reconstruction analysis of the flight trajectory compiled according to the data of the Russian Bird Ringing Centre (Figure 6) allowed us to determine the population distribution geography for the birds regularly migrating along the western coast of the Caspian Sea and refine borders of the West Siberian-East African migration 


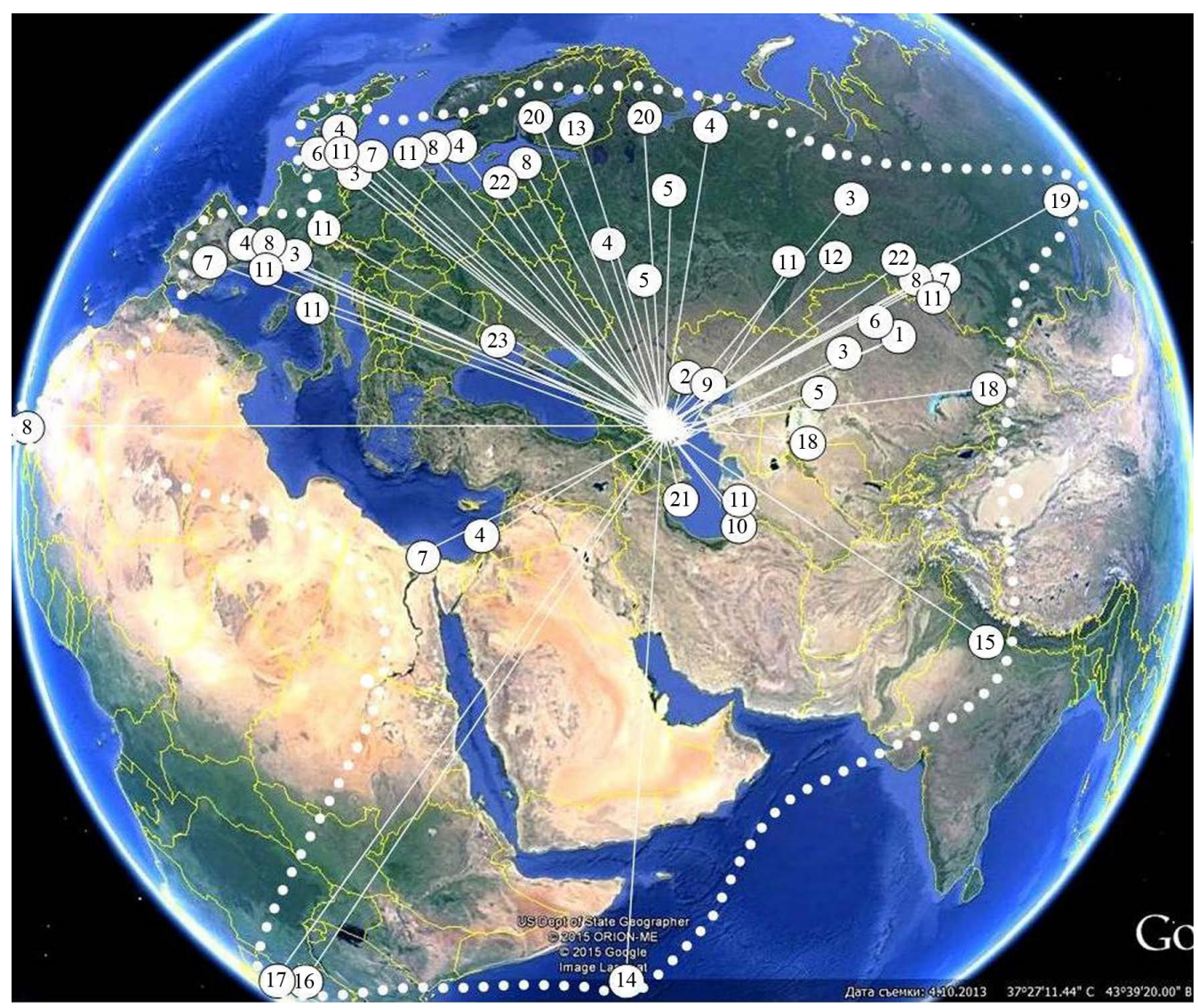

Figure 6. Schematic map of the bird migration trajectory (data of the Russian Bird Ringing Centre). Twenty-three taxa are used: 1. Anser Anser; 2. Cygnus olor; 3. Anas platyrhynchos; 4. Anas crecca; 5. Anas strepera; 6. Anas penelope; 7. Anas acuta; 8. Anas querquedula; 9. Anas clypeata; 10. Netta rufina; 11. Aythya ferina; 12. Bucephala clangula; 13. Pandion haliaetus; 14. Arenaria interpres; 15. Himantopus himantopus; 16. Calidris ferruginea; 17. Calidris alba; 18. Larus ichthyaetus; 19. Larus minutus; 20. Larus fuscus; 21. Larus cachinnans; 22. Larus canus; 23. Larus genei.

range (Figure 1). Thus, according to our data, the current migratory range should be greatly extended to cover the area from the British Isles in the West Palearctic to Lake Baikal in the east, including the extreme west and south of Africa.

In conclusion, we should note that in the event of realization of the predicted transgression scenario of the World Ocean [1], the proposed scheme of the coastal wetland ecosystem evolution may serve as a pattern to be applied to the world's coasts. For example, only among coasts of the Caspian Sea, lying within the CIS countries, the lagoon coasts with well-expressed bars in their modern relief make up 38\%. And adding the Iranian coast where conditions for the development of coastal barriers are especially favourable gives the figure of $50 \%$ of the total length of the Caspian coastline [15].

To justify avifaunal importance of the considered lagoons we on a ranking basis distinguished a key group of birds comprising 50 taxa (Table 1) [20]. These taxa are included in the IUCN Red List of Threatened Species and in the Red Data Books of Russian and Daghestan alongside with 134 bird species having a conservation status in Europe. On this count, Sulakskaya and Turalinskaya lagoons are regarded as IBAs of Russia and included in the shadow list of Ramsar sties [21].

However, at the present time both these lagoons are under threat of total destruction, and we suggest a set of measures to be implemented for their restoration that is especially urgent for Turalinskaya Lagoon. It requires as follows:

1) To dig a network of canals in the lagoon bottom profile (leaving a central island part for bird nesting) with radial branches along the canal axis. It will substantially increase the length of the shoreline and provide additional shelters for birds (Figure 7). 
Table 1. Rare and threatened bird species in lagoons of Daghestan with indication of their conservation status, residence status and abundance trend.

\begin{tabular}{|c|c|c|c|}
\hline № & Species and conservation status & $\begin{array}{l}\text { Residence } \\
\text { status }\end{array}$ & $\begin{array}{l}\text { Date of records and/or abundance trend } \\
\text { Trend corresponds to residence status }\end{array}$ \\
\hline 1 & Pelecanus onocrotalus_-Great White Pelican *** R, D & $\mathrm{P}$ & $\mathrm{OF}$ \\
\hline 2 & Pelecanus crispus—Dalmatian Pelican * R, D & P, IW & $\mathrm{O}+1, \mathrm{OF}$ \\
\hline 3 & Phalacrocorax pygmaeus_-Pygmy Cormorant ** R, D & $\varnothing, \mathrm{P}, \mathrm{W}$ & LF, M-1, O-1 \\
\hline 4 & Bubulcus ibis_-Cattle Egret R, D & $\mathrm{P}$ & $\mathrm{L}+1$ \\
\hline 5 & Platalea leucorodia-Eurasian Spoonbill ** R, D & $\mathrm{P}$ & $\mathrm{L}+1$ \\
\hline 6 & Plegadis falcinellus - Glossy Ibis *** R,D & $\mathrm{P}$ & O-1 \\
\hline 7 & Ciconia ciconia-White Stork ** D & IP & 8 ind. 04.10.1995; 8 ind. 23.10.1998; 4 ind. 08.05.2009 \\
\hline 8 & Phoenicopterus roseus_-Greater Flamingo R, D & $\mathrm{P}$ & LF \\
\hline 9 & Rufibrenta ruficollis—-Red-breasted Goose R, D & IP, $\Theta$ & 33 ind. 03.02.1997; 1 ind. 10.12 .1998 \\
\hline 10 & Anser erythropus - Lesser White-fronted Goose * R, D & IP & L-2 \\
\hline 11 & Cygnus bewickii-Bewick’s Swan * R, D & 如, IP, W & $\begin{array}{l}4 \text { ind. 03.03.1998; } 25 \text { ind. 05.02.1998; } \\
18 \text { ind. 20.01.2006 }\end{array}$ \\
\hline 12 & Anas angustirostris—-Marbled Teal * R, D & 安, IP & 07.06.2001 a pair in Sulakskaya Lagoon \\
\hline 13 & Aythya nyroca-Ferruginous Duck * R, D & $\bullet, \mathrm{P}, \mathrm{W}$ & OF, O-1, L-1 \\
\hline 14 & Melanitta fusca-Velvet Scoter *** R, D & IW & $\begin{array}{c}12 \text { ind. 29.12.1998; } 2 \text { ind. 06.01.1999; } 1 \text { ind. 11.01.999; } 2 \\
\text { ind. 22.01.1999; } 4 \text { ind. 04.02.2005 }\end{array}$ \\
\hline 15 & Oxyura leucocephala-White-headed Duck * R, D & 市, IW & From $\quad 28.12 .2002$ to 08.01 .2003 - 2 ind. \\
\hline 16 & Pandion haliaetus-Osprey *** R, D & $\mathrm{P}$ & $\mathrm{L}-2$ \\
\hline 17 & Circus macrourus-Pallid Harrier *** R, D & $\mathrm{P}$ & LF \\
\hline 18 & Accipiter brevipes_-Levant Sparrowhawk ** R, D & IP & $\operatorname{Re} ?$ \\
\hline 19 & Buteo rufinus—Long-legged Buzzard *** R, D & 媇, S & $\begin{array}{c}1 \text { ind. 08.07.2005; } 1 \text { ind. 07.10.2005; } 1 \text { ind. 06.03.2008; } 1 \\
\text { ind. 18.04.2008; } 1 \text { ind. 17.04.2010 }\end{array}$ \\
\hline 20 & Hieraetus pennatus-Booted Eagle *** D & IP & $\mathrm{UF}$ \\
\hline 21 & Aquila rapax-Tawny Eagle *** R, D & $\mathrm{P}$ & $\mathrm{ReF}$ \\
\hline 22 & Aquila clanga—Spotted Eagle * R, D & IP & 10 ind. 19.05.2000; 2 ind. 23.03.2007 \\
\hline 23 & Aquila pomarina-Lesser Spotted Eagle *** R, D & IP & $\begin{array}{l}1 \text { ind. 22.04.1997; } 1 \text { ind. } 19.11 .2004 \text {; } \\
1 \text { ind. 30.12.2009 }\end{array}$ \\
\hline 24 & Aquila heliaca-Imperial Eagle * R, D & IP & 1 ind. 03.07.2004 г.; 1 ind. 12.12.2008 \\
\hline 25 & Aquila chrysaetos_-Golden Eagle *** R, D & IP & 2 ind. 21.11 .1995 г.; 2 ind. 11.04 .1997 \\
\hline 26 & Haliaeetus albicilla-White-tailed Eagle $* * *$ R, D & $\mathrm{P}, \mathrm{W}$ & $\mathrm{L}+2, \mathrm{OF}$ \\
\hline 27 & Falco cherrug—Saker *** R, D & $\mathrm{P}$ & $\begin{array}{l}1 \text { ind. 15.10.1998; } 1 \text { ind. 05.11.2004; } \\
1 \text { ind. 22.09.2005; } 1 \text { ind. 03.11.2006 }\end{array}$ \\
\hline 28 & Falco peregrinus-Peregrine $* * *$ R, D & $\mathrm{P}, \mathrm{S}$ & Reo, Reo \\
\hline 29 & Falco naumanni-Lesser Kestrel * R, D & $\mathrm{R}, \mathrm{P}$ & $\mathrm{L}+1, \mathrm{~L}+1$ \\
\hline 30 & Grus leucogeranus-Siberian Crane R, D & IP & 12 ind. 04.10.1995 \\
\hline 31 & Anthropoides virgo_-Demoiselle Crane R, D & $\mathrm{P}, \mathrm{S}$ & O-1, L-1 \\
\hline 32 & $\begin{array}{c}\text { Porphyrio porphyrio-Grey-headed Swamphen } * * * \text { R, } \\
\text { D }\end{array}$ & $\mathrm{R}, \mathrm{WT}$ & $\mathrm{O}-2, \mathrm{LF}$ \\
\hline 33 & Otis tarda—Great Bustard * R, D & IP & $\mathrm{U}-2$ \\
\hline 34 & Tetrax tetrax —-Little Bustard ** R, D & $\mathrm{P}$ & $\mathrm{O}+1$ \\
\hline 35 & Burhinus oedicnemus-Eurasian Stone-curlew *** R, D & $\mathrm{B}, \mathrm{P}$ & $\begin{array}{l}\text { Lo, L-1 Since } 2003 \text { one pair has regularly nested at the } \\
\text { shore of Sulakskaya Lagoon }\end{array}$ \\
\hline 36 & Charadrius asiaticus_-Caspian Plover *** R, D & IP & 2 ind. 07.04.1999; 4 ind. 21.09.2001; 3 ind. 04.09.2009 \\
\hline 37 & Vanellus leucura-White-tailed Plover *** R, D & IP & $\begin{array}{c}4 \text { ind. } 08.05 .1998 ; 1 \text { ind. } 13.10 .2005 ; 2 \text { ind. } 11.09 .2009 ; 8 \\
\text { ind. } 17.09 .2009 ; 1 \text { ind. } 11.09 .2009 .\end{array}$ \\
\hline
\end{tabular}




\section{Continued}

\begin{tabular}{|c|c|c|c|}
\hline 38 & Himantopus himantopus_-Black-winged Stilt R, D & B, P, WT, S & $\mathrm{OF}, \mathrm{O}+1, \mathrm{UF}, \mathrm{ReF}$ \\
\hline 39 & Recurvirostra avocetta—Pied Avocet *** & $\mathrm{P}$ & L-1 \\
\hline 40 & Haematopus ostralegus_-Eurasian Oystercatcher R, D & $\mathrm{PB}, \mathrm{P}$ & LF, L-1 \\
\hline 41 & Numenius tenuirostris—Slender-billed Curlew R & 凉!, IP & $\begin{array}{c}1 \text { ind. 23.07.1997; } 6 \text { ind. 04.05.2000; } 1 \text { ind. } 12.05 .2000 ; 3 \\
\text { ind. 28.07.2005; } 1 \text { ind. 15.09.2006 }\end{array}$ \\
\hline 42 & Numenius arquata-Eurasian Curlew *** R, D & $\mathrm{P}, \mathrm{N}$ & L-1, L-1 \\
\hline 43 & Glareola pratincola-Collared Pratincole *** R, D & PB, P & LF, L-1 \\
\hline 44 & $\begin{array}{c}\text { Glareola nordmanni-Black-winged Pratincole } * * * \mathrm{R}, \\
\mathrm{D}\end{array}$ & PB, P & OF, L-1 \\
\hline 45 & Larus ichthyaetus—Great Black-headed Gull R, D & $\varnothing, \mathrm{P}, \mathrm{WT}$ & L-2, O-1, L-2 \\
\hline 46 & Hydroprogne caspia-Caspian Tern *** R, D & IP & UF \\
\hline 47 & Sterna albifrons-Little Tern $* * *$ R, D & $\mathrm{B}, \mathrm{P}$ & L-1, L-2 \\
\hline 48 & Pterocles orientalis—Black-bellied Sandgrouse ${ }^{* * *} \mathrm{D}$ & 安 & 13 ind. 20.03.1998 \\
\hline 49 & Bubo bubo-Eurasian Eagle-owl *** R, D & $\mathrm{S}$ & 1 ind. 20.11.1997 \\
\hline 50 & Lanius exubitor-Great Grey Shrike *** R, D & $\mathrm{P}$ & LF, LF \\
\hline
\end{tabular}

Notes: Species name and conservation status. Code: SPEC 1 -species of global conservation concern-*; SPEC 2-species has an unfavourable conservation status in Europe and is concentrated in Europe-**; SPEC 3-species has an unfavourable conservation status in Europe, but is not concentrated in Europe_*** [20]. Letters: R—species is listed in the Red Data Book of Russia; D—species is listed in the Red Data Book of Daghestan. Residence status. Code: $\mathrm{R}$ —resident (partially resident), regularly nesting; $\mathrm{B}$ —nesting migrant or bird of passage; $\varnothing$ - formerly nesting, at the early stages of the lagoon successions; PB—probably nesting; •-nesting not every year; P-occurring on passage (birds from the local population are not taken into account); W-wintering (staying for at least ten days in winter); WT-wintering transiently (staying in winter for 1 - 5 days); IW—wintering not every year; $\mathrm{N}$-summering (occurring during nesting season but definitely not nesting); IP_accidental species (occurring irregularly or accidentally); S-flies in from adjacent areas (visitor); $\Theta$ - species no longer occurs on passage; $\$$ - new species in the study area. Date of records and/or abundance trend. Code: F-abundance fluctuates without any distinct trend;? — trend is unknown; U—single individuals (less than 0.1 ind. $\left./ \mathrm{km}^{2}\right)$; Re-rare $\left(0.1\right.$ - 1.0 ind. $\left./ \mathrm{km}^{2}\right)$; L-low abundance $\left(1.1-10.0\right.$ ind. $\left./ \mathrm{km}^{2}\right)$; O—common species $\left(10.1\right.$ - 100.0 ind./km $\left.{ }^{2}\right)$; o—stable abundance; -1 -abundance decreased by $5 \%-20 \%$; -2 - abundance decreased by more than $20 \%$.

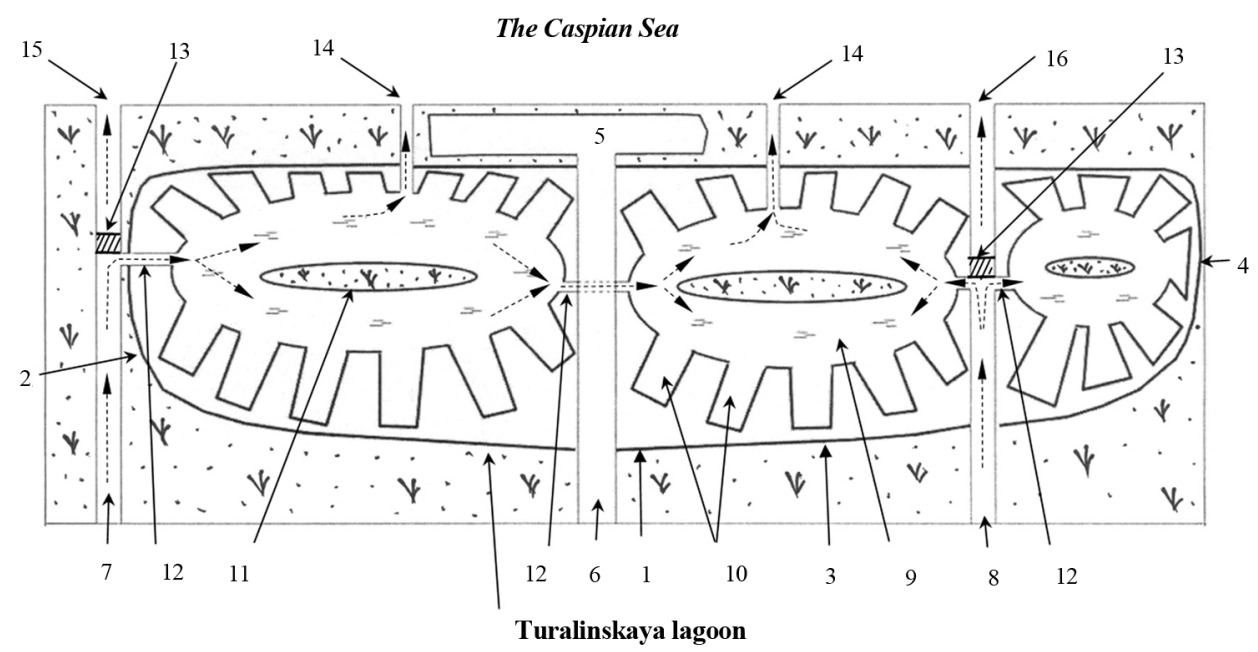

Figure 7. Schematic map showing the hydrological reconstruction of Turalinskaya Lagoon. Notes: 1. Turalinskaya Lagoon. 2. Northern part of the lagoon. 3. Central part of the lagoon. 4. Southern part of the lagoon. 5. Beach. 6. Road to the beach; 7. Talginka River. 8. Uytashsky Collector Canal. 9. Axial canal. 10. Radial branches of the canal. 11. Artificial island. 12. Water-supply canal. 13. Discharge canal. 14. Mouth of Talginka River. 15. Mouth of Uytashsky Collector Canal. Legend: dashed arrow shows the direction of water flow.

2) To redirect waters from the Uytashsky Collector Canal and Talginka River to Turalinskaya Lagoon (its northern, central and southern parts). To dig additional drainage channels to the sea to discharge extra water that will facilitate the renewal of permanent water flow and prevent the lagoon from muddying.

The implementation of this set of hydrotechnical actions directing at the rehabilitation of Turalinskaya Lagoon will not only lead to the improvement of qualitative and quantitative composition of bird and fish fauna in 
this wetland but will also provide a perfect test area for scientific studies and a kind of open-air classroom for trainings of student environmentalists, ornithologists, hydrobiologists and ichthyologists of Daghestan, Russia and other countries of the world.

\section{References}

[1] Sokolov, L.V. (2010) Climate in Life of Plants and Animals. “TESSA” Publishing House, Saint Petersburg, Russia, 2010. (In Russian)

[2] Baranov, A.L. (2006) General Trends in Dynamics of Bird Ranges in Middle Siberia. In: Belik, V.P., Ed., Ornithological Studies in Northern Eurasia, Stavropol State University Press, Stavropol, Russia, 67-68. (In Russian)

[3] Belik, V.P. (2003) Large-Scale Transformations of East European Avifauna in the $20^{\text {th }}$ Century and Their Possible Causes. Ornitologiya, 30, 25-31. (In Russian)

[4] But'ev, V.T. (2006) Dynamics of Bird Ranges and Ornithogeographic Zoning. In: Belik, V.P., Ed., Ornithological Studies in Northern Eurasia, Stavropol State University Press, Stavropol, Russia, 104-105. (In Russian)

[5] Vilkov, E.V. (2013) Population Trends in Regular Migrants as the Basis for a Prediction Model for Conservation of the Birds of Eurasia. Russian Journal of Ecology, 44, 142-157. http://dx.doi.org/10.1134/S106741361301013X

[6] Mundkur, T., Galbraith, C. and Heredia, B. (2011) Promoting a Strategic Approach for the Conservation of Migratory Waterbirds Globally. Abstract Book of the International Conference on the Waterfowl of Northern Eurasia, Elista, Kalmykia, Russia, 24-29 March 2011, 29. (In Russian)

[7] Mikheev, A.V. (1977) The Visible Migration of Waterbirds during Daylight Hours along the Western Coast of the Caspian Sea, Stavropol, Russia. (In Russian)

[8] Boere, G.C. and Stroud, D.A. (2006) The Flyway Concept: What It Is and What It Isn't. In: Boere, G.C., Galbraith, C.A. and Stroud, D.A., Eds., Waterbirds around the World, The Stationery Office, Edinburgh, UK, 40-47.

[9] Isakov, Y.A. (1967) MAR Project and Conservation of Waterfowl Breeding in the USSR. In: Salverda, Z. Ed., Proceedings of the Second European Meeting on Wildfowl Conservation, Noordwijk aan Zee, The Netherlands, 9-14 May 1966, 125-138. Ministry of Cultural Affairs, Recreation and Social Welfare, The Netherlands.

[10] Krivenko, V.G. and Vinogradov, V.G. (2008) Waterbirds and Climate Rhythms in Northern Eurasia. Vaisfel'd, M.A. and Martynov, A.S., Eds., RAEAN Press, Moscow, Russia. (In Russian)

[11] Svitoch, A.A. (1998) Geoecological Disaster in the Coastal Cities of Dagestan. Priroda, 5, 16-17. (In Russian)

[12] Vilkov, E.V. (2004) Dynamics of Dagestan Lagoons and its Influence on Bird Communities along the Western Coast of the Caspian Sea. Theses for the Degree of PhD in Biology, Moscow, Russia. (In Russian)

[13] Vilkov, E.V. (2014) Genesis and Evolution of Caspian Lagoons as Important Avifauna Refuges at the Western Coast of the Caspian Sea. Problemy Regionalnoi Ekologii, 2, 191-197. (In Russian)

[14] Vilkov, E.V. (2006) Evolution of Freshwater Lagoons in Daghestan and their Importance for Waterbirds on the West Caspian Coast. In: Boere, G.C., Galbraith, C.A. and Stroud, D.A., Eds., Waterbirds around the World, The Stationery Office, Edinburgh, UK, 372.

[15] Ogorodov, S.A. (1998) Morphology and Dynamics of Present Transgressive Bars of the Caspian Sea. Theses for the Degree of PhD in Geography, Moscow State University Press, Moscow, Russia. (In Russian)

[16] Ravkin, Yu.S. and Dobrokhotov, B.P. (1963) On the Census Methods for Birds of Forest Landscapes in the Non-breeding Season. In: Organizations and Census Methods of Birds and Harmful Rodents, Publishing house AN of the USSR, Moscow, Russia, 130-136. (In Russian)

[17] Ravkin, Yu.S. (1967) On the Census Methods for Birds of Forest Landscapes. In: Wildlife in Hotbeds of Tick-Borne Encephalitis in Altai, Nauka, the Siberian Branch, Novosibirsk, Russia, 66-75. (In Russian)

[18] Rusanov, G.M. (2001) Abundance of Waterbirds in the Volga Delta under Unstable Water Regime (1968-1999). Bulletin of Goose Study Group of Eastern Europe and North Asia, 7, 365-383. (In Russian)

[19] Gistsov, A.P. (2001) Abundance of Waterbirds in the North-Eastern Caspian Coast. In: Current Issues of Study and Conservation of Birds of Eastern Europe and North Asia, Proceedings of the International Conference (11th Ornithological Conference), “Matbugat Yorty” Publishing House, Kazan, Russia, 174-176. (In Russian)

[20] Tacker, G.M. and Heath, M.F. (1994) Birds in Europe: Their Conservation Status. Bird Life International, Cambridge, UK.

[21] Vilkov, E.V. and Dzhamirzoev, G.S. (2000) Sulakskaya Lagoon. Turalinskaya Lagoon. In: Sviridova, T.V. and Zubakin, V.A., Eds., Important Bird Areas of Russia, Russian Bird Conservation Union, Moscow, Russia, 386-387. (In Russian) 